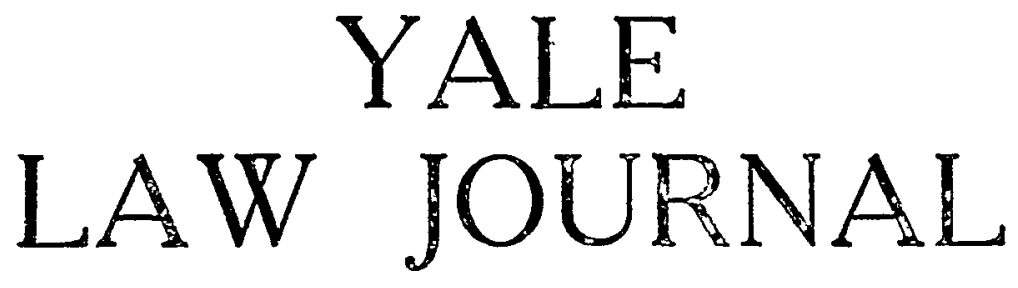

Vol. XXXVI

DECEMBER, 1926

No. 2

\title{
MOTOR CARRIER REGULATION BY CERTIFICATES OF NECESSITY AND CONVENIENCE
}

\section{DAVID E. LILIENTHAL AND IRWIN S. ROSENBAUMA}

Within the past five years the motor vehicle for hire has developed from insignificance to a formidable position in our transportation system. Motor busses, for years confined to short-haul traffic wholly within large cities, now swarm the inter-city and inter-state highways of the country, operating upon regular schedules throughout the year.1 The motor truck has revolutionized short-haul shipping and terminal operations.: So long as the motor vehicle was employed chiefly for private

IThe following table summarizes bus operation, as of January 1, 1926; by January 1, 1927 these numbers will be increased about $931 / 8 \mathrm{~s}^{\circ}$ if the same annual rate of increase is maintained for 1926 which obtaincd for 1925.

\begin{tabular}{|c|c|c|c|}
\hline $\begin{array}{l}\text { Common Carriers } \ldots \ldots \ldots \ldots \ldots \\
\text { Non-Common Carriers } \ldots \ldots \ldots\end{array}$ & $\begin{array}{c}\text { No. of } \\
\text { Vehicles } \\
28,145 \\
29,605\end{array}$ & $\begin{array}{l}\text { No. of } \\
\text { Companies } \\
6,455 \\
15,177\end{array}$ & $\begin{array}{c}\text { Miles of } \\
\text { Route } \\
232,310.6 \\
334,401\end{array}$ \\
\hline Total & & 21,632 & $566,741.6$ \\
\hline
\end{tabular}

This census of vehicles, according to a careful survey, covers only $80 \%$ of the total, which is placed at 70,000. Loomis, How the Bus Industry is Built Up (1926) 5 Bus Transfortation, 69 at seg.

2 For a single example: The Pennsylvania Railroad has displaced local freight trains by trucks on one thousand miles; its trucks serve 500 stations with 650 tons of less-than-carload shipments daily. See (1926) 81 RAIIWAY AGE, 595 ff.

See articles published by the MIotor Truck Committee, National Automobile Chamber of Commerce, Co-ordinatcd Transportation Scrics (19231925) Numbers 1-13; Report of Special Committee $I V$ of the Chamber of Commerce of the United States (1923); Budd, The Rclation of Highzay Transportation to the Railway, address before the American Socicty of Civil Engineers, April 14, 1926, at Kansas City, Mro.; Powell, Funetion of the Motor Truck in Reducing Cost and Prevcrating Congestion of Frcight 
use, it presented no grave problem of regulation. The cities and states could feel that their duty had been fulfilled by the enactment of safety regulations, traffic rules, speed laws, or laws to protect the highway from abuse. But when the motor vehicle suddenly developed on a huge scale into a public carrier, such regulations became wholly inadequate, and the legislatures were not slow to respond to the need for a different type of regulation-a regulation not simply of the physical operation but of the business now "affected with a public interest." ${ }^{3}$

The motor carrier ${ }^{4}$ presented to the legislatures at least three kinds of regulatory problems, all requiring for their solution some limitation upon those seeking entrance into this field of carriage. The first problem was to protect the costly public highways from over-use by hordes of competing motor carriers employing giant vehicles, ${ }^{5}$ and to render the highways less hazardous for pedestrians and riders. The then existing motor vehicle laws regulating physical operation. were generally inadequate. The second problem and one more difficult, complicated as it was with economic implications, arose out of the vigorous competition between these new carriers, with their relatively small investment, and the established steam and electric railways. ${ }^{6}$ Passenger revenues on short-haul traffic had

in Railroad Terminals (1924) 116 ANNALS OF THE AMER. ACAD. of POLITICAL AND SOCIAL SCIENCE, 87; see also infra note 93.

3 During the past three years 25 states have brought carriers under state regulation by special enactments or greatly changed their existing laws.

1923: California, Maine, Michigan, Montana, Ohio, Oklahoma, Rhodo Island, Virginia; 1925: Indiana, Iowa, Kansas, Massachusetts, Minnesota, Nevada, North Carolina, North Dakota, Oregon, South Dakota, Vormont, Wisconsin, Wyoming; 1926: Louisiana, Mississippi, Kentucky, Now Jersey.

4 Although many statutes describe this class of carriers as "motor vohicles for hire" or "auto transportation companies," the term "motor carrier" seems preferable and is common in recent enactments. See Iowa Acts 1925 , c. 5 ; Kan. Laws 1925 , c. $206, \S 1$ (b) ; Okla. Laws 1923, c. 113, § 1 (b) ; S. D. Laws 1925, c. 224 . See also Ill. Commerce Comm. Gen Ordor 116 , rule 1.

- Most states have been forced to impose restrictions upon weight, width, number of trailers, etc.; such restrictions upon excessively large or heavy vehicles are usually to be found in the highway statutes, often administored by a highway commission or its equivalent. E.g. Me. Laws 1921, c. 211, $\S 25$, c. 187 , c. $211, \S \S 16,17,18,20$; W. Va. Code Ann. (Barnes, 1023) c. $43, \S 12$. The lengthy preamble to Nev. Laws 1925 , c. 161, states that the operation of heavy motor vehicles "is known to rapidly destroy the said roads and improved highways so as to increase the cost of maintenanco -. ."; similar declarations appear, in one form or another, in othor statutes.

${ }^{6}$ In reversing an order of the Illinois Commerce Commission, granting a certificate to a bus line which was in competition with rail carriers, Mr. Justice Thompson made the following extreme comment: 
already been seriously invaded by the private automobile when the motor carrier entered the field on a big scale; more and more local trains were abandoned.7 The electric railways suffered even more than the steam; thousands of miles of track were abandoned; passenger receipts fell one-third. ${ }^{8}$ The third problem was closely related to the second: the cut-throat competition between motor carriers themselves, fatal to the public

"The savings of hundreds of thousands of investors have been massed to build our great network of railroads, and these transportation systems are entitled to protection from irresponsible competition. If shoestring transportation companies, with no money invested in right of way and no reserve capital . . . are permitted to drop in here and there and talie the cream of the transportation business from the permanent transportation systems, disastrous results are inevitable." Choate v. Commerce Comm., 309 IIl. 248, 256, 141 N. E. 12, 15 (1923).

And in Re Application of McClain (1924) Ohio Pub. Util. Conm. Ilocliet No. 3234, the Ohio commission made the following interesting comment:

"Counsel for the applicants contend that as the present Norfoll \& Western Railway superseded the canal, which, in turn, had superseded the stage coach, and, as to passenger trafic and local parcel freight, had been superseded between Chillicothe and Columbus by the traction line, the public automobile is here as the successor of the electric railway .. . We are keenly aware of existing conditions in the transportation field and believe that the law here involved has as much purpose of conserving existing transportation facilities as of stabilizing the new service."

"In 1920 class I steam carriers produced a total of $46,848,688,000$ passenger miles; in 1925 this had shrunk to $35,963,862,000$. In 1920 the railroads carried 1,269,912,000 passengers; in 1925 the figure was $856,650,000$, the lowest passenger carriage since 1908. See Trumbower, Economies of Highway Transportation (1926) 31 JouRnal of THE WESTERN SOCETY OF ENGINEERS, 147. It has been stated that the $25 \%$ decline in rail passenger business is confined chiefly to short haul traffic. Slater, The Motor-Bus as a Competitor of the Railroads (1926) 2 JouRNar of LuND \& PonLrC UTHITY ECONONIICS, 129, 131.

The figures for the first six months of 1926 show a continued decrease in passengers carried. See Statistics of Railuays of the Unitcd States, Interstate Commerce Commission, June 30, 1926.

In recent testimony before Interstate Commerce Commissioner Esch, investigating the motor carrier situation, similar injury to freight business was disclosed. For example, on the Denver \& Rio Grande Western, for the year ending February 28, 1921, less than carload shipments between Denver and Trinidad totalled 19,967 tons, with a revenue of $\$ 191,035$; for the year ending February 28,1926 , the tonnage was 13,110, and the revenue $\$ 139,425$. (Testimony taken in Docket No. 18300). See (1926) 5 Bus Transportation, 593.

8 In the past 10 years 54 electric railway companies have abandoned all operation, 97 have abandoned rail service entirely, now rendering eervice by motor-bus, and 79 have abandoned part of their rail system, replacing it with bus service. See Replacement of Electric Railuays by Busses (1926) 5 Bus Transportation, 72. On the loss of revenues see staternent of Charles L. Henry, General Counsel, American Electric Railway Aszociation: Hearings before Interstate Commerce Committee on S. 2306, 69th Cong. 1st Sess. 98 (MTarch, 1926). 
need for efficient permanent service. It is our purpose to discuss the efforts of the states, through legislature, commission and court, to meet these latter-day problems of regulation.

With few exceptions, comprehensive regulation of motor carriers begins with a grant of power to the existing public utility commission, either by a special act applicable alone to motor carriers, by a statute specifically placing the new kind of public utility under the general public utility act, or by construction of existing provisions to include them. Where commission regulation has been adopted, it has been coupled with the requirement that before motor carriers may begin operation, they must obtain from the commission a certificate or permit, evidencing the commission's opinion that the "public convenience and necessity" require such operation. ${ }^{9}$ This has been the legal device which the legislatures and their agents, the commissions, have employed in their efforts to control the economic situation produced by the rise of the motor carrier. In our discussion it will only be necessary, therefore, to treat of certificates of convenience and necessity.

\section{HISTORY AND NATURE OF CERTIFICATES}

The formula of "public convenience and necessity" is by no means a new one. For many years the phrase-or its alternative, "common convenience and necessity"-ran through the highway construction statutes. A state statute would impose a duty to build highways in certain localities, if in the judgment of those in authority such construction was required by "public

${ }^{9}$ Ariz. Acts 1919, c. 130; Calif. Gen. Laws (Deering, 1923) Act 5129; Colo. Comp. Laws (1921) § 2914; Conn. Pub. Acts 1921, c. 77, § 3; Ill. Rov. Stat. (Cahill, 1923) c. 111a, § 71; Ind. Acts 1925, c. 46, § 2; Iowa Acts 1925 , c. $5, \S 4$; Kan. Laws 1925 , c. 206 , $\S 5$; Ky. Act of March 5,1026 , $\S$ 3; La. Act of July 15, 1926, § 3; Me. Laws 1921, c. 184 and Me. Laws 1025, c. 211; Md. Ann. Code (Bagby, 1924) art. 56, $\S \S 255,262$; Mass. Acts 1025, c. 280 ; Mich. Pub. Acts 1923, No. 209; Minn. Laws 1925, c. 185, \& 5 (a); Miss. Laws 1926, c. 128 , $\S 1,6$; Mont. Laws 1923, c. $154, \S 4$; Nov. Laws 1925 , c. $161, \S 3$; N. H. Laws 1919 , c. $86, \S 2 ;$ N. Y. Cons. Laws (Cahill, 1923) c. $64, \S 26 ;$ N. C. Laws " 1925 , c. 50 , § 3 ; N. D. Laws 1925 , c. 91, § 5; Pa. Stat. (West, 1920) §§ 18150, 18088; 1 Ohio Gen. Code (Pago, 1926) $\S \S 614-87,614-88$; Okla. Laws 1923 , c. $113, \S 4$; R. I. Gen. Laws 1923 , § 3724; S. D. Laws 1925, c. 224 ; S. C. Acts 1925, No. 170; Utah Comp. Laws (1917) § 4818; Vt. Laws 1925, No. 74, § 2; Va. Acts 1924, c. 222; Wash. Laws 1921, c. 111, § 4; W. Va. Code (Barnes, 1925) c. 43, § 82; Wis. Stat. 1925, $\$ 194.02$. The Arkansas commission's assumption of jurisdiction without such a statutory requirement has very recently been hold to be unjustified. Arkansas Railroad Comm. v. Independent Bus Lines, 285 S. W. 388 (Ark. 1926). Wyoming's commission also makes this requirement, relying upon Wyo. Laws 1915 , c. $146, \S 45$, although this section does not seem to sustain the jurisdiction. 
convenience and necessity" ; the enforcement of the duty, that is, the application and construction of the phrase, was imposed upon the courts. ${ }^{10}$ The test was also employed in the direct statutory regulation of public utilities which preceded the era of commission control. So, in Re Shelton Railzay, 11 the statute regulating street railways denied such carriers the right to build their lines parallel to a steam or electric road unless a county court should return a finding that "public convenience and necessity required" the construction; in its opinion the court discusses the meaning of the phrase. ${ }^{12}$ Although common enough in state public utility legislation, until the Transportation Act, 1920, amending the Interstate Commerce Act, this expedient had apparently not been employed in the regulation of interstate commerce. By paragraphs 18, 19 and 20 of section 1 of that Act ${ }^{13}$ Congress required all carriers under the jurisdiction of the Act to secure such a certificate before extending their old lines or constructing new ones, or before acquiring or operating a railroad or extension; the same requirement was laid down before any carrier might abandon any part of its line.

The primary purpose of requiring motor carriers to secure certificates of convenience and necessity "is not regulation with a view to safety or to conservation of the highways, but the prohibition of competition. It determines not the manner of use, but the persons by whom the highways may be used. . . . [It] is designed primarily to promote good service by excluding unnecessary competing carriers." 14 It effects this purpose in at least two ways : first, by giving the commission the power to refuse to permit motor carrier operation in a given territory where the existing transportation facilities seem to meet the public need or convenience, or where the motor applicant seems for any reason unfit; second, it gives an authorized motor carrier a right of substance in which he will be protected, upon application to the commission or the courts, against uncertified carriers seeking to compete with him.

${ }^{10}$ See Fenwick Hall Co. v. Town of Old Saybrook, 69 Conn. 32 (1897).

1169 Conn. 626 (1897).

12 The court said at 631: "So in the statute under consideration, the 'public convenience and necessity' sufficient to 'require the construction of such street railway,' means a condition existing at the time of the application, in respect to the applying railroad, the mode of public travel, the manner in which those needs are to supplied, and the probable effect of the proposed road upon the whole question of adequately supplying those nerds - . . that, in the judgment of the trier, will justify the interference with private rights involved."

1341 Stat. 456, at 477-478, (1920) U. S. Comp. Stat. (Supp. 1923) §§ $8563(17)-8563(20)$.

14 Mr. Justice Brandeis, for the court, in Buck v. Kuykendall, 267 U. S. 307, 315, 45 Sup. Ct. 324, 326 (1925). 
The object of a certificate does not seem to be to grant a legal monopoly, nor is its effect in practice the same as a franchise monopoly; for, if the need for additional service justifies, it is the duty of the commission to grant additional certificates to other qualified applicants. The number of certificates in a certain field is limited only by the demands of public necessity and convenience. Some statutes or regulations specifically deny that a certificate is the grant of a monopoly. ${ }^{15}$ The effect is certainly to regulate and restrict competition between carriers, by deciding which one or ones shall be allowed to operate, and then regulating their business while protecting them from the sompetition of the unauthorized. ${ }^{16}$ While the certified carrier benefits, this is said to be incidental to the purpose of insuring reliable, continuous and efficient service for the community. ${ }^{17}$ The prospect of a public utility seeking and being granted legal protection against competition is not a new one. It has been pointed out that such famous cases as the Charles River Bridge case $^{18}$ and the Binghampton Bridge case ${ }^{19}$ are early instances. ${ }^{20}$

There has been some discussion in the cases as to the legal nature of a certificate of public convenience and necessity, but only after a considerable accretion of decisions has formed about the statutes can an authoritative definition be formulated. That the certificate, in the hands of one authorized to operate under it, is an interest of substance, a property right, seems clear. ${ }^{21}$ In case after case, the courts have granted injunctions to certificate holders against unauthorized operation along the same route by other motor carriers. Almost all the statutes provide means whereby the commissions may protect certificate holders by action against unauthorized operation. ${ }^{22}$ It is the opinion of the Utah Supreme Court that "such a certificate is in

15 See Ill. Rev. Stat. (Cahill, 1923) c. 111a, § 71; Mont. Laws 1923, c. $154, \S 4$; N. D. Laws 1925, c. $91, \S 4$; and see Vt. Gen. Laws (1917) $\S 5068$, and in Re James, 132 Atl. 40 (Vt. 1926). The Illinois provision seoms utterly without meaning in view of such a case as Egyptian Transportation System v. Louisville \& N. R. R., 321 Ill. 580, 152 N. E. 510 (1926).

16 See an excellent note in (1920) 33 HARv. L. REv. 576.

17 See Choate v. Commerce Comm., supra note 6.

18 Charles River Bridge Co. v. Proprietors of Warren Bridge, 11 Pet. 420 (U. S. 1837).

18 The Binghampton Bridge, 3 Wall. 51 (U. S. 1865).

20 (1920) 33 HaRv. L. REv. 576, 577.

21 The property which a certificate holder receives is an additional illustration of the creation by the law-maker (in this instance, the legislaturo and its agent) of a property right, that is, a right to act which the stato will protect or enforce. See Calder v. Bull, 3 Dall. 386, 394 (U. S. 1798); Eaton v. Railroad, 51 N. H. 504, 511 (1872) ; 2 AUSTIN, LECTURES ON JURISPRUDence (1863) 35; Abbot, The Police Power and the Right to Compensation (1889) 3 HARv. L. REv. 189, 190.

22 See infra page 193. 
the nature of a limited franchise, and authorizes the grantee in the certificate to operate a utility over the designated routes and likewise protects him against interference by the others unless authorized by the commission." 23 The fact that the certificate is revokable for cause, after hearing, does not seem to change its character as a property right, since by the terms of the statutes the certificates are granted upon the condition that they may be revoked for certain causes or within the judgment of the commission. ${ }^{24}$ The privileges appertaining to such certificates, like the benefits granted by a franchisess have been held to be non-transferable, and personal to the grantee. "It has been the theory of the Public Utility Commission," said IIr. Justice Robinson in Estabrook v. Public Utilities Commission of Ohio, ${ }^{26}$ "that the motor transportation act was enacted for the purpose of promoting the public convenience and necessity and not for the purpose of creating a property right in any particular route in the recipient of any such certificate; that whatever personal advantage inures to such recipient is an incident to the carrying out of the purpose of serving the public convenience and necessity, but is not an object of the act; that the certificate is personal in character, and does not pass by assignment, succession, descent, or by any other process, from the recipient to any one else." ${ }^{27}$ Many statutes provide, however, that a certificate may be transferred, if the commission gives its approval..s

In the meager light which the courts have shed upon the legal

${ }^{23}$ See Public Utility Comm. v. Garviloch, 54 Utah, 406, 414, 181 Pac. 272, 275 (1919). See also Re Yakima-Northern Stages, Inc., Pub. Util. Rep. 1925 C. 220 (Wash. 1925) where it was said that a certificate is subject to the protection granted property by the due process of law clause.

${ }^{24}$ See infra page 189.

25 See 2 Wyman, Public Service Corforations (1911) § 1426.

26112 Ohio St. 417, 419, 147 N. E. 761, 762 (1925). By change in the Ohio statute, the certificates now pass by descent. See Ohio Gen. Code (Page, 1926) § 614-87a.

${ }^{27}$ See also Red Ball Transit Co. v. Public Utilities Comm., 112 Ohio St. 462,147 N. E. 762 (1925).

28 Ariz. Acts 1919 , c. $130, \S 3$ (e); Calif. Gen. Lavs (Deering, 1923) Act 5129, $\S 5 ;$ D. C. Ann. Code (1924) appendix, Pub. Util. par. 54; Iowa Acts 1925, c. 5, \$ 11; Ky. Act of March 5, 1926, § 12; Minn. Lavs 1925, c. 185 , $\$ 9$; Miss. Laws 1926 , c. 128, $\$ 9$; Mont. Laws 1923, c. $154, \S d$; N. J. Laws 1926, c. 144, § 3; N. C. Laws 1925, c. 50, § 3(d) (5); N. D. Laws 1925 , c. 91, § 5; Or. Gen. Laws (Spec. Sess.) 1921, c. 10, \& 4; S. D. Laws 1925, c. 224, § 12; Wash. Laws 1921, c. 111, \$ 4; W. Va. Code (Barnes, 1925) c. $43, \S 82$.

In Kansas a purchaser or assignee seems to have a right to the privileges of the certificate purchased regardless of commission approval. Kan. Laws 1925 , c. $206, \S 4$. In Michigan there can be no assignment of permits. Mich. Pub. Acts 1923, No. 209, $\S 1$. In Ohio the personal representative of a deceased certificate holder succeeds to his ancestor's rights thereunder, out in cases of other transfers, or continuation by surviving partners, the transfer must be approved. 1 Ohio Code (Page, 1926) 614-57a. 
position of the certificate of convenience and necessity, it seems to be revealed as sui generis, standing somewhere between a franchise on the one extreme, and a mere license on the other. It is well established that a franchise or consent granted to a corporation, when accepted or acted upon, becomes property of which it is said the grantee cannot be "deprived without due process of law and without compensation." In Colonial Motor Coach Corporation v. City of Oswego, ${ }^{29}$ the common council, by ordinance, granted a "consent" to the plaintiff motor bus company to operate an inter-city route through the city. The company then applied to the public service commission for a certificate, but a decision upon the application had not been made when the council withdrew the "consent." The court granted the plaintiff's motion continuing an injunction pendente lite, and held that the "consent," acted upon by the company, constituted a franchise and a contract which the council could not constitutionally revoke. The court brushed aside the argument that "consent" to operate the bus route and a franchise are different things, saying, "To my mind it is not necessary to draw any finespun distinctions between a franchise and a consent, or to decide whether the ordinance . . . was technically one or the other. That resolution conferred a privilege upon the plaintiff to operate its busses over the streets named, without which it would have been unlawful for the plaintiff to so do." ${ }^{30}$ Presumably this court would have regarded the revocation of a certificate of convenience in a similar light. ${ }^{31}$

Contrasted with the care with which the holder of a franchise must be handled, so long as he is complying with its terms and fulfilling his obligations, is the uncertain tenure of a licensee. The holder of a city license to operate a motor vehicle may have his license revoked at will, and without a hearing. ${ }^{32}$ In Burgess v. Brockton ${ }^{33}$ the court said, "The petitioners have been licensed to transport passengers for hire. Their investment is not by its nature so irrevocably devoted to that service as is that of the street railway," and accordingly the license was treated as a. mere privilege or permission, and was revoked when its exercise adversely affected the city's street railway system.

Somewhere between these two extremes of an inviolable right

20126 Misc. 829, 832, 215 N. Y. Supp. 159, 162 (1926). The leading cases on the point are collected at 831, $215 \mathrm{~N}$. Y. Supp. at 161.

${ }^{30}$ But cf. Re Troy Auto Car Co., Pub. Util. Rep. 1917A 700 (N. Y. 1917).

31 The question is of more than academic interest since the New York statute does not seem to contain the usual broad and specific powor to revoke.

32 See Burgess v. Brockton, 235 Mass. 95, 126 N. E. 456 (1920); Focheo v. State, 15 Ala. App. 113, 72 So. 685 (1916); Chicago v. Gall, 195 Ill. App. 41 (1915); LaPlante v. State Board, 131 Atl. 641 (R. I. 1926).

${ }^{83}$ Supra note 32 , at 101,126 N. E. at 460. 
and a mere permission, stands the certificate of convenience and necessity. It seems safe to prophecy that as the bus companies become more and more stable, their investrnent greater, their service more regular and their good will highly important, certificates will come to be treated in most respects as rights of substance, subject to full protection as property, and revolable only by the strict terms of their issuance. The decisions certainly indicate a rapid trend in that direction. ${ }^{35}$

\section{THE ISSUANCE OF CERTIFICATES}

The requirement of a certificate from the commission as a condition precedent to operation as a motor carrier is usually to be found in the statute which vests jurisdiction over such carriers in the commission. Such statutes not infrequently prescribe the form of application which must be made to the commission, and require a hearing to be had thereon after notice has been given to interested parties, who may intervene." Some general public utility acts require all enterprises under the act to secure such certificates before beginning operation, or before extensions are made; hence where motor carriers have been brought under commission regulation by legislative re-definition, or by commission construction of the terms "common carrier" and "public utility," certificates have been required of them." Recently the Arkansas commission assumed jurisdiction of motor

34 A computation made by Merrill B. Knox, Esq., assistant editor of Evs Transportation, from financial balance sheets and other couress indicates that as of June 1,1926, the capital investment in the passenger motor carrier industry was $\$ 743,228,181$. Of this sum $\$ 422,505,181$ is represented by common carrier companies. These figurcs include not only rolling stock but also equipment, including terminal and garage facilities. The valuation of the steam railroads of the country is estimated to be between 15 and 30 billions of dollars.

${ }^{35}$ See discussion infra, especially of enforcement of certificates by holders.

${ }^{36}$ For examples of statutes prescribing the manner of application, sce: Kan. Laws 1925 , c. 206, $\S 4$; Minn. Laws 1925 , c. 185, $\S 5$ (b) ; N. C. Laws 1925 , c. $50, \S 3$ (a) ; S. D. Laws 1925 , c. $224, \S \S 8$ (b), 9 (b).

For examples of provisions specifically requiring commission hearings upon applications, see: Conn. Pub. Acts 1921, c. 77, \$ 3; Ind. Acts 1925, c. $46, \S 2$; Iowa Acts 1925, c. 5, 5 ; Kan. Laws 1925, c. 206, $\$ 4$; Ky. Act of March 5, 1926, $\S 14$; N. C. Laws 1925, c. $50, \S 3$ (b) (c). But ef. Wash. Laws 1921, c. 111, § 4, and 1 Ohio Gen. Code (Page, 1926) \$ 614-37.

For examples of provisions requiring notice of a hearing to be served on interested parties, as competing rail carriers, local authorities, etc., who may intervene and present evidence, see $\mathrm{Ky}$. Act of March 5, 1926, $\$ 14$; Minn. Laws 1925, c. 185, $\$ 6 ; 1$ Ohio Gen. Code (Page, 1926) §614-91; Vt. Laws 1925, No. 74, $\$ 2$.

37 See, for examples: Colo. Comp. Laws (1921) § 2914; Ill. Rev. Stat. (Cahill, 1923) c. 111a, $\$ 71$; Pa. Stat. (West, 1920) $\S \S 18088$, 18150; Wyo. Comp. Stat. (1920) $§ 5497$. 
carriers under the general language "common carrier," and required certificates of convenience before operation, although the public utilities act under which it proceeded lays down no such requirement for any public utilities. ${ }^{38}$ The Supreme Court has just held, however, that the statute does not sustain this assumption of jurisdiction. ${ }^{39}$

It is of the essence of a certificate of public convenience and necessity that its issuance lies within the discretion of a commission. A statute which requires the issuance of a "permit" as a matter of right, if the operator complies with certain defined conditions, is not the kind of certificate we have here under consideration. The permits required in Oregon and Idaho seem to be of this variety. ${ }^{40}$ The model uniform statute, prepared in 1923 by the motor vehicle committee of the National Association of Railroad and Utilities Commissioners, made provision for such "permit" to a limited class of operators, those not on a regular schedule between fixed termini.41 Some such scheme is employed in a few states, either by statute or by commission regulation, ${ }^{42}$ and the proposed federal regulatory measure adopted the classification method for interstate carriers. ${ }^{43}$ The general rule is, however, that all carriers which are regulated at all, are required to obtain the same authorization; not a mere registration, but a certificate that public convenience and necessity require the operation.

\section{CLASSES OF CARRIERS OF WHOM CERTIFICATES ARE REQUIRED}

To what kinds of motor carriers does the requirement extend? Upon this question there is great diversity in the statutes, the

${ }^{38}$ In Re the Petition of the Arkansas Traveler Company for Establishment of Rules \& Regulations governing Common Carriers of Passengers by Bus between Cities within the State of Arkansas, Case No. 507, Dec. 15,1925 , amended March 26, 1926, same case number. Jurisdiction was assumed by virtue of: Ark. Acts 1921, Act 124, $\S 5$.

${ }^{30}$ Arkansas R. R. Comm. v. Independent Bus Lines, 285 S. W. 388 (Ark. 1926). McCulloch, C. J., and Wood, J., dissented.

$\$ 0$ Or. Laws (Spec. Sess.) 1921, c. 10, $\$ 4$, provides for a permit which must be issued to all applicants who will comply with certain simple requirements; this statute was replaced in 1925 by a comprehensive law providing for genuine discretionary permits, but its effect was suspended until a referendum in November, 1926. See also Idaho Laws 1925, c. $197, \S 4$.

41 See 35 NAT'L Ass'N of R. R. AND Utilities Commissioners (Proceedings 35th Annual Convention, 1923) 177 et seq.

42 See S. C. Acts 1925, No. 170, $\S 2,4$ (five classes) ; S. D. Laws 1925, c. $224, \S 10$ (four classes); Va. Acts 1924 , c. $222, \S \S 3,5$ (a) (four classes); and see Case No. 507, Railroad Commission of Arkansas, Amendment to Order, March 26, 1926 (three classes).

${ }^{43}$ See S. 1734, a bill to regulate interstate commerce by motor vehicles operating as common carriers on the public highways, 69th Cong. 1st Sess. For further discussion of this measure see infra page 180. 
differences turning principally upon four factors: (1) the uses to which the carrier is put; (2) whether carriage is regular and between fixed termini, or irregular; (3) whether the operation is as a common carrier or a private carrier; (4) the geographical extent of operation.

(1) Exemptions from the operation of acts requiring certificates are frequently extended on the basis of the use to which the carrier puts his facilities. Such exemption sometimes extends to all freight carriers, as in New York and Massachusetts; ${ }^{44}$ other common exemptions include taxi-cabs, ${ }^{45}$ hotel and sightseeing busses, ${ }^{46}$ school and church busses ${ }^{4 r}$ and carriers transporting agricultural or dairy products to market from the point of production.s ${ }^{\text {s }}$ The majority of these exemptions have

$\$ 4$ N. Y. Cons. Laws (Cahill, 1923) c. $64, \$ \S 25,26$, as construed by the commission in Re Graves, No. 7562 (2d Dist.) decided June 15, 1926; Miass. Acts 1925, c. 280.

45 Calif. Gen. Laws (Deering, 1923) Act 5129, $\$ 1$; Ky. Act of March 5, 1926, § 27a; La. Act of July 15, 1926, § 1 (f); Minn. Laws 1925, c. 185, § $2(f)$; Miss. Laws 1926, c. 128, $\$ 3(f), 3(\mathrm{~h})$; Nev. Laws 1925, c. 161, $\$ 1$; N. J. Laws 1926, c. 144, § 2, c. 146, § 2; N. D. Laws 1925, c. 91, § 1 (D); 1 Ohio Gen. Code (Page, 1926) $\$ 614-84$ (a); Or. Gen. Laws. (Spee. Sess.) 1921 , c. $10, \S 1$ (c); Va. Acts 1924, c. $222, \S 9$; Wyo. Laws 1025, c. 150.

Some states expressly. include taxicabs. MId. Acts 1920, c. 677; W. Va. Code (Barnes, 1925) c. 43, $\$ 82$. In those states regulating irregular operators, taxicabs would be subjected to regulation, unless the state commission has no authority over carriers exclusively within cities. New Jersey has just enacted a special taxicab act, N. J. Laws 1926, c. 249 . See injra note 54 .

48 Calif. Gen. Laws (Deering, 1923) Act 5129, $\$ 1$; Ky. Act of Siarch 5, 1926, § 27a; N. C. Laws 1925, c. 50, § 2; 1 Ohio Gen. Code (Page, 1926) § 614-84a; S. C. Acts 1925 , No. $170, \S 2$; Va. Acts 1024, c. $222, \S 2$ deal with sightseeing busses. As to hotel busses, see Minn. Laws 1025, c. 185, $\$$ 2 (f); Nev. Laws 1925, c. 161, 1 ; N. J. Laws 1926, c. 144, $\$ 2$; 1 Ohio Gen. Code (Page, 1926) § 614-84a; N. D. Laws 1925, c. 91, 1 (D). For an interesting case involving the status of such carriers, see Chicago Motor Coach Co. v. Edgewater Beach Hotel, 5 Ill. Commerce Comm. 049 (1926).

As of Jan. 1, 1926, there were 2,520 busses operating in these two elassifications. Loomis, op. cit. supra note 1 , at 71 .

17 Idaho Laws 1925, c. 197, §1; Iowa Acts 1925, c. 5, § 1 (a); Kan. Laws 1925 , c. $206, \S 1$ (d); La. Act of July 15, 1926, § 1 (f); Mtinn. Laws 1925, c. 185, § 2 (f); MIiss. Laws 1926, c. 128 , § 3; N. J. Laws 1026, c. 144, $\$ \mathbf{2}$, c. $146, \S 2 ; N$. C. Laws 1925 , c. 50, § 2; N. D. Laws 1925, c. 11 , 1 (D); 1 Ohio Gen Code (Page, 1926) $§ 614-84 a$; S. C. Acts 1925, No. 170, $\$ 2$; S. D. Laws 1925 , c. $224, \$ 1$ (i); Va. Acts 1924 , c. $222, \$ 2$.

It is estimated that 500,000 students daily use motor carriers in regular school serrice. See Govert, Schools Spcnd \$30,000,000 Ycarly To Transport Pupils (1926) 5 Bus Transportation, 175.

18 Calif. Gen. Laws (Deering, 1923) Act 5129, § 5; Kan. Laws 1925, c. 206, $\$ 1$ (d) ; Minn. Laws 1925 , c. $185, \S 2$ (f); Mont. Laws 1923, c. 154, $\S 1$ (e) ; Miss. Laws 1926 , c. $12 S, \S 3$; N. C. Laws 1925, c. 30, $32 ; \mathrm{N}$. D. Laws 1925, c. $91, \S 1$ (D); Or. Gen. Laws (Spec. Sess.) 1921, c. 10, $\$ 1$ (e); S. C. Acts 1925 , No. 170 , § 2; S. D. Laws 1925, c. $224, \S 1$ (i); Va. Acts 1924 , c. $222, \S 2$. In Montana and Oregon it is provided that the commis- 
been sustained by the courts against charges of arbitrary and unreasonable classification..$^{40}$

(2) The regulation of motor carriers that do not operate over a regular route and between fixed termini presents serious difficulties of administration to the commissions. ${ }^{50}$ Accordingly, many statutes exclude them from the regulation through certificates imposed upon regular operators, either by limiting the application of the statute to such regular operators, or by requiring certificates of convenience and necessity of regular operators and some different form of authorization for irregular oper. ators. ${ }^{51}$ Similar distinctions have been made by commissions, even where the statute contains no such limitation..$^{02}$

sion may exempt "the transportation of freight or passengers by motor vehicle in rural communities when not done on a commercial basis."

The reasons for this exemption are given by Mr. Kuykendall, who was then Director of Public Works of Washington, 35 NAT'L ASS'N OF R, R. AND UTILITIES Commissioners, supra note 41 , at 183 and 166.

40 See State v. Johnson, 243 Pac. 1073 (Mont. 1926) ; Smallwood v. Jeter, 244 Pac. 149 (Idaho, 1926) and such analogous cases as Ex parte Hoffert, 34 S. D. 271, 148 N. W. 20 (1914); Thielke v. Albee, 79 Or. 48, 153 Pac. 793 (1916) ; Bacon Service Corp. v. Huss, 248 Pac. 235 (Calif. 1926).

But some of the exemptions have been held arbitrary. See State v. Crosson, 33 Idaho, 140, 190 Pac. 922 (1923); Franchise Motor Freight Ass'n v. Seavey, 235 Pac. 1000 (Calif. 1925).

50 "The original auto transportation acts in several states undertook tho regulation of companies operating between fixed termini or over a regular route only. Practical experience has disclosed that freight trucks and forhire passenger cars, maintaining stands in the various cities and towns, are operating over the routes covered by the certificates of convenience and necessity issued to the auto transportation companies and are keenly competitive therewith. The major portion of the service performed by these concerns consists of freight tranfer business and passenger taxicab operations in the various towns and eities; but, when opportunity presents itself, these companies transport persons and property between towns, cities and localities over routes covered by certificates of convenience and necessity. These independent operators do not come within the purview of most of the regulatory acts. . . . They escape all regulation. . . . They frequently engage in cut-throat competition with each other and with certifcate holders to their own detriment and to the injury of regular certified operators and ultimately to the detriment of public service." $35 \mathrm{~N} \Lambda \mathrm{T}^{\prime}{ }^{\prime}{ }_{4}$

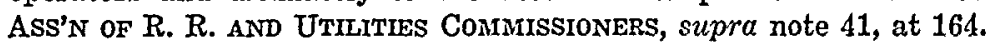

51 Calif. Gen. Laws (Deering, 1923) Act 5129, § 1 (c); 3 Colo. Ann. Stat. (Courtright's Mill's, 1924) § 5933r; Conn. Pub. Acts 1921, c. 77, § 1; Iowa Acts 1925, c. 5, $\S 1$ (a); Ky. Act of March 5, 1926, §§ 3, 21, 21a; Me. Laws 1923, c. 211, § 1; Md. Ann. Code (Bagby, 1924) art. 56, §§ 255, 262, semble; Mass. Acts 1925, c. $280, \S 1$; Mich. Pub. Acts 1923, No. 209, 1 ; Minn. Laws 1925 , c. 185 , $\S \S 1,2$; Miss. Laws 1926, c. 128 , $\S \S 3$ (h), 5 (distinction in degree of regulation only); Mont. Laws 1923, c. 154, § 1 (c); N. J. Laws 1926, c. 144, § 2; Okla. Laws 1923, c. 113, §1 (b); Vt. Laws 1925, No. 74, $\S 1$; Wash. Laws 1921, c. 111, § 1 (d).

52 See Ark. Railroad Comm., Case No. 507, as amended March 26, 1926; Ill. Commerce Comm., General Order 116, June 4, 1924, rule 1; Or. Pub. Serv. Comm., Order 1297, effective Jan. 1, 1926. 
Not the least difficult task in administering motor carrier laws lies in the interpretation of these terms "regular routes" and "fixed termini." A typical instance is People v. Car $\% \%^{53}$ The defendants operated taxi-cabs from the railroad station at MIuskegon, and solicited passengers to go to Hart, a neighboring city. On the return trip they would transport anyone who wished to go from Hart to MIuskegon. Ordinarily a taxi-cab does not operate over a regular route and between fixed termini, ${ }^{\text {ss }}$ In the opinion of the court there was nothing illegal in the defendants' operating frequently between the two cities, upon the request of patrons; they "could not, however, establish a service between Hart and MIuskegon, or elsewhere, under schedule, or even intermittent, for the purpose of rendering a general auto bus service to the public, in competition with the auto bus service under state regulation, without a permit to do so from the Commission." $\varepsilon 5$ Upon a consideration of the facts it appeared that defendants were actually operating regularly, hence illegally.

(3) Whether existing statutes and commission orders require certificates of convenience and necessity of prizate carriers, that is, those who do not offer their services to the public at large indiscriminately to the limit of their canacity, presents a dificult question, not only of administration but also of constitutional law. A company serving all comers must first secure a certificate and be subject to commission regulation. If another company performing identical service over the same route, but as a "private" carrier under special contract with one or more patrons, may operate without such certificate, and in unregulated competition with such certified carriers, a real strain is put upon the entire regulatory scheme. The same considerations which led the legislatures to require certificates of common carriers apply with almost equal force to private carriers for hire: there is the same injury to the highway due to over-erowding, the same hazard to pedestrian and riding public, the same destruction of sound and continuous service through uniestricted competition.56 Accordingly, many state statutes have employed

53231 Mich. 246, 206 N. W. 948 (1925).

*4 See Schnader, The Taxical-Its Scrice and Rrgulation (1025) 116 Annals of the Amer. Acad. of Political axd Sociar Schicice, 101.

5s People v. Carr, strpra note 53, at 249, 206 N. Wr. at 940.

56 "Upon principle, however, we perceive no reason why the rule should not apply with equal force to the case of a private carrier who proposes to use the street as a place of private business or as a chief instrumentality thereof. The rule does not rest upon the circumstance alone that the carrier is engaged in operating a public utility and that his business is therefore affected with a public interest, but it rests equally upon the circumstance that he is using the public highways as the chicf instramentality of a private business conducted for private gain. In other words, he is enjoying a special privilege in the highways which are constructed 
language broad enough to include private carriers within their requirements of certificates, ${ }^{5 \pi}$ and some of the commissions have construed the statutory language to include such carriers. The Michigan commission, for example, made such a construction, and a private carrier sought and was granted an injunction against the commission, restraining it from enforcing the Act (which included a provision requiring certificates of convenience) against the complainant. Upon appeal, the Supreme Court of the United States, in Public Utilities Commission v. Duke, ${ }^{\text {,s }}$ affirmed the decree of the lower court, and held invalid that section of the act which declared all motor carriers for hire to be common carriers, subject to common carrier regulation. The court did not hold, however, that a state could not constitutionally require certificates of convenience of private carriers, although at least one state court subsequently so misconstrued the decision..$^{59}$ The holding of the court is summed up in the following statement:

"It is beyond the power of the state by legislative fiat to convert property used exclusively in the business of a private carrier into a public utility or to make the owner a public carrier, for that would be taking property for public use with-

and maintained at public expense and designated for the common uso of all." Frost v. Railroad Comm. of California, 240 Pac. 26, 29 (Calif. 1926).

57 In the following states, regulation extends to all motor vehicles upon the highways operating "for hire" or "for compensation": Idaho Laws 1925, c. $197, \S 1$; Me. Laws 1923 , c. $211, \S 1$; Mass. Acts 1925 , c. 280 , $\$ 1$, adding "as a business . . ."; N. C. Laws 1925 , c. $50 ;$ N. D. Laws 1025, c. 91 , § 1 (D); Okla. Laws 1923, c. 113, \& 1 (b); Wash. Laws 1921, c. 111, \$\$ 1 (d), 2; W. Va. Code (Barnes, 1925) c. 43, 82 (h); Wyo. Laws 1925, c. 150. The phrase "in the business of transporting persons or property . . . or as a common carrier for compensation . . " is used in Calif. Gen. Laws (Deering, 1923) Act 5129, § 1; Mont. Laws 1923, c. 154, 1 (c); Or. Gen. Laws (Spec. Sess.) 1921, c. 10, 11 (c). A similar phrase is used in the new Kentucky statute, Act of March 5, 1926, § 1. Indiana and Ohio expressly exclude private carriers. Ind. Acts 1925, c. 46, § 5. See also S. C. Acts 1925, No. 170, § 4; S. D. Laws 1925, c. 224, § 2 (a); Va. Acts 1924, c. $222, \S 3$. The statutory situation in Ohio is worthy of special note. Section 614-84 of the Code (Page, 1926) applies the Act to "common carriers for hire, under private contract or for the public in general" but not to "private contract carriers." Section 614-2 defines the latter as motor vehicles "under private contract but not as common carriers" to which carriers alone the Act as a whole applies. The same section defines "motor transportation companies" as motors operating "under private contract or for the public in general . . ." as common carriers. The Act of 1023 was construed in Hissem v. Guran, 112 Ohio St. 59, 146 N. E. 808 (1925) to exclude private carriers upon the authority of Michigan Pub. Util. Comm. v. Duke, 266:U. S. 570, 45 Sup. Ct. 191 (1925). Hence the Act was amended in 1925 by inserting "under private contract" as a clause of exclusion.

58 Supra note 57.

59 Hissem v. Guran, supra note 57. 
out just compensation, which no state can do consistently with the due process of law clause of the 14th Amendment." $c_{3}$ But the court did not hold that requiring a certificate of convenience of a private carrier violated the due process of law clause. Nor can it be said that requiring such a certificate as a condition precedent to the operation of a private carrier "convert[s] property used exclusively in the business of private carrier into a public utility or . . . make[s] the owner a public cairier," a legislative metamorphosis which the court did hold violated the due process clause.

The California commission had likewise required certificates of private carriers; an appeal from the commission's order was presented to the California Supreme Court after the decision in the Duke case. This court upheld the commission, but in the opinion wandered afield from the points necessarily raised by the appeal. ${ }^{\text {B1 }}$ Mr. Chief Justice Aireyers stated that the same obligations which could constitutionally be imposed upon common carriers, might be imposed upon private carriers for hire. "Upon principle," he continued, "we perceive no reason why the rule should not apply with equal force to the case of a private carrier. . . . The rule does not rest upon the circumstance alone that the carrier is engaged in operating a public utility and that his business is therefore affected with a public interest, but it rests equally upon the circumstance that he is using the public highways as the chief instrumentality of a private business conducted for private gain. In other words he is enjoying a special privilege in the highways which are constructed and maintained at public expense and designated for the common use of all." Although the commission's order could have been affirmed without treading upon such uncertain ground, the court said that the state could require that all carriers using the highways for business purposes should be subject to all common carrier duties and regulations. But the requirement of a certificate of a private carrier (which is what the commission had ordered) does not, of course, necessarily effect any such radical result.:2

In Frost v. Railroad Commission of Califormio, ${ }^{\text {‘9 }}$ the United

${ }^{60}$ Supra note 58, at 577, 45 Sup. Ct. at 193.

61 The only issue was whether the commission's desisting order should have been sustained. See the dissenting opinion of Mr. Justice Holmcs in Frost v. Railroad Comm., 46 Sup. Ct. 605, 610 (U. S. 1926).

62 The California court sought to distinguish the Duke case on the ground that the contracts had been entered into before the enactment of the legislation in question, so that subsequent regulatory legislation impaired those contracts, whereas in the Frost case the legislation was in effect when the contracts were made. There is nothing in the Dulie opinion to sustain this distinction.

${ }^{63}$ Supra note 61. 
States Supreme Court, in its most recent pronouncement in this field, reversed the California judgment. The court condemned the assumption of the California court that a private carrier can, as a condition of operation upon the highways, be required to submit to common carrier obligations, and stated that this is simply one way of converting a private carrier into a common carrier by legislative command, a result forbidden by the due process clause. But the court did not hold that the states may not require certificates of private carriers. "The case presented," wrote Mr. Justice Sutherland, for the majority, "is not that of a private carrier, who, in order to have the privilege of using the highways is required merely to secure a certificate of public convenience and become subject to regulations appropriate to that kind of carrier, but it is that of a private carrier, who, . . . must submit to the condition of becoming a common carrier. . . ." There is here no holding that private carriers may not be constitutionally certified, without violence to the Constitution; in fact, the inference is to the contrary. ${ }^{64}$ The holding is simply that private carriers may not be so regulated, whatever the means, as to convert them from private into common carriers, subject to all those common law and statutory obligations of continuity and equality of service, etc., to which common carriers must submit.

(4) The geographical extent of a carrier's operations has been made a basis for exemption or inclusion in the class from which a certificate is exacted. For example, the statutes in some states do not require those motor carriers to obtain a certificate whose operation is wholly within a city, or between contiguous cities $;^{65}$ hence only inter-city operators must pass the "public convenience and necessity" test. Even in states

64 The opinion of the dissenting judges is explicit upon the point.

65 This provision is found in Calif. Gen. Laws (Deering, 1923) Act 5129, § 5, but cf. § 4; Idaho Laws 1925, c. 197; Ill. Rev. Stat. (Cahill, 1923) c. $111 \mathrm{a}, \S 100$ (if cities accept juxisdiction by referendum); Ind. Laws 1925, c. 46, §5 (subject to conditions); Kan. Laws 1925, c. 206, §1 (d) ; Ky. Act of March 5, 1926, $\$ 27$ a (as to streets not maintained in wholo or part by other than local funds); Mass. Gen. Laws (1921) c. 159, $\S 47$ (with appeal to state authority) ; Mich. Pub. Acts 1923, No. 209, §§ 1, 8; Mont. Laws 1923, c. $154, \S \S 1$ (c), 3; Nev. Laws 1925, c. 161, § 1; N. J. Laws 1926 , c. 144 , $\S 2$, but cf. Laws 1911, c. 195, $\S 24$; New York Cons. Laws (Cahill, 1923) c. $64, \S 25$, c. $49, \S 5$ (1), c. $64, \S 26$, c. $27, \S 288$; N. C. Pub. Laws 1925 , c. $50 ;$ N. D. Laws 1925 , c. $91, \S 1$ (d); 1 Ohio Gon. Code (Page, 1926) § 614-84 (and including territory contiguous to municipality); Okla. Laws 1923, c. 113, \& 2; Or. Gen. Laws (Spec. Sess.) 1021, c. $10, \S 1$ (c); S. D. Laws 1925, c. 224 , § 1 (i); Va. Laws 1924, c. 222, § 9; Va. Laws 1923, § 3712; Wash. Laws 1923, c. 79, $\S 1$ (d); Miss. Laws 1926, c. $128, \S \S 3$ (b), (h), 18. See also Perrysburg v. Ridgway, 108 Ohio St. 245, 140 N. E. 595 (1923); Red Star Motor Drivers Ass'n v. Public Utilities Comm., 209 N. W. 146 (Mich. 1926). 
in which all motor carriers, regardless of the region in which they operate, must obtain certificates, municipalities often have wide powers of regulation over such matters as speed, equipment, routes and the like. In some states as in MIassachusetts and New York the consent of the municipalities through which an operator proceeds is a condition precedent to the issuance of a certificate for the entire route by the commission. ${ }^{3}$

In the absence of federal regulation of motor carriers operating in interstate commerce, the states for years sought to exercise some measure of control over such carriers, yet without violation of the commerce clause. It was generally believed by the commissions that with Congress "silent," si the states might require certificates of interstate carriers to safeguard their highways and particularly to prevent the virecking of ints:a- and interstate motor carriage alike by cut-throat competition. In requiring certificates of such carriers, and imposing other regulations, the commissions and the courts supporting them relied upon a line of Supreme Court decisions approving the imposition upon interstate motor carriers of state license taxes, drivers' licenses, and registration for service of piocess. ${ }^{c 3}$ But in two recent decisions the United States Supreme Court has held that the denial by a state of certificates of convenience and necessity to exclusively interstate carriers is an undue and unreasonable burden upon interstate commerce. ${ }^{9}$ Such certificates are not in the nature of "police" regulations, but prohibit or limit the right to operate in interstate commerce, and such result the states are powerless to effect, under the commerce clause, despite the "silence" of Congress. In the previously decided Dulce case the commerce clause was also involved, but the court did not

${ }^{66}$ See Miass. Acts 1925 , c. 280 , but of. Mrass, Gen. Laws (1921) c. 159, $\$ 47$. The 1926 legislature amended the statute so that a single city along a route cannot, by withholding its consent, prevent the Department of Public Utilities from issuing a certificate if the other cities have given their consent. $C f$. Atchison T. \& S. F. Ry. v. Public Utilities Comm., 77 Colo. 42, 234 Pac. 175 (1925); Norfolk Southern Ry. v. Commonvealth, 141 Va. 179, 126 S. E. 82 (1925) ; N. Y. Cons. Laws (Cahill, 1923) c. 64, $\$ 25$, c. $49, \S 5$ (1) ; N. J. Laws 1926, c. 144, $\$ 2$, but cf. N. J. Laws 1911, c. $195, \S 24$; N. J. Laws 1926, c. 44, § 3, and c. 146, § 2; Utah Comp. Stat. (1917) $\$ 1818$; Wash. Comp. Stat. (Remington, 1922) $\$ 6282$ (as to firstclass cities); W. Va. Code (Barnes, 1925) c. 43; Wis. Stat. 192\%, $\$ 191.07$.

67 For analysis of the decisions which indicate the extent to which state regulation may go, where there is no federal action, see Franlifurter and Landis, The Compact Clause of the Constitution (1025) 34 YALE LAW JOURNAL, 685, 721 et seq.

6s Hendrick v. Maryland, 235 U. S. 610, 35 Sup. Ct. 140 (1915); Kane v. New Jersey, 242 U. S. 160, 37 Sup. Ct. 30 (1916). See also Smith v. Alabama, 124 U. S. 465, s Sup. Ct. 564 (188s); Nashville, C. \& St. L. Ry. จ. Alabama, 128 U. S. 96, 9 Sup. Ct. 28 (18s8).

69 Buck v. Kuykendall, 267 U. S. 307, 45 Sup. Ct. 324 (1925); Bush v. Maloy, 267 U. S. 317, 45 Sup. Ct. 326 (1925). 
pass directly upon the constitutionality of state certification of an interstate carrier.

These decisions at once produced no end of confusion. ${ }^{70} \mathrm{~A}$ movement for a federal statute was at once set on foot, and a legislative proposal to meet the situation was drafted and introduced into Congress. ${ }^{11}$ Extended hearings were held on this bill during the last session of Congress. Under its provisions, certificates of convenience are required of all interstate motor common carriers. Jurisdiction to grant or deny certificates is vested jointly in the commissions of the states through which the carrier proposes to operate. It seems not unlikely that legislation patterned in general along the lines of this bill will be enacted within the next few sessions of Congress. Meanwhile the states may require interstate operators carrying intrastate as well as interstate passengers, to obtain certificates covering the operation within the state, so long as such requirement does not result in unreasonably burdening the interstate carriage. ${ }^{22}$

\section{CONSIDERATIONS FOR COMMISSIONS IN THE ISSUANCE OF CERTIFICATES}

When a motor carrier makes application to a commission for authority to operate, the commission must pass upon a difficult question, and one predicated upon an economic problem: does the public necessity and convenience require the commission to authorize this additional transportation service? Applying this indefinite test to a complex set of facts calls for the exercise of administrative and business judgment of the highest order.

In many states, when motor carriers were first subjected to commission regulation, the legislatures lightened their initial burden by providing that carriers operating in good faith on

70 In Illinois, for example, in 1925, before the Buck and Bush decisions, there were 6 busses operating interstate; at the end of the year, following those decisions, there were 121 so operating who held Illinois intrastate certificates, and 125 others holding no certificates from any state. See testimony of Chester Moore, Esq., executive vice-president, Illinois Motor Transportation Association. Hearings before the Interstate Commerce Commission in Docket 18300, Motor Bus and Trucl: Investigation, Chicago, Illinois, July 28, 1926; see also a comment on the Rhode Island situation in (1926) 5 BUS Transportation, 52; Slater, op. cit. supra note 7, at 133; Hearings before Interstate Commerce Committee on S. 1734, 69th Cong. 1st Sess. 210.

71 The bill, known as S. 1734, was drafted by a special committee of the National Ass'n of Ry. and Utilities Commissioners, headed by John E. Benton, its general solicitor, and modified in conferences with the interests represented by the Nat'l Automobile Chamber of Commerce, the Bus Division of the American Automobile Ass'n, the American Electric Ry Ass'n, the Ass'n of Ry. Executives and the American Short Line Ry. Ass'n. The details of this important proposal may be found in (1926) 26 Cor. L. REv. 954 .

72 Haselton v. Interstate Stage Lines, Inc., 133 Atl. 451 (N. H. 1926). 
a certain date, generally prior to or at the date of the passage of the motor regulation statute, upon filing an application and proving affirmatively such operation, were entitled to certificates as a matter of right."3 The basis for such a provision, called a "grand-father clause," is simply one of fairness-that a man who has developed a useful business should not have it suddenly taken from him; and the notion that if a carrier has been operating successfully, it is at least prima facie evidence that the public necessity and convenience require him to continue.

The classification made between prior and subsequent bus lines has been upheld as constitutional under the equal protection clause. ${ }^{73}$ The provision has been said to be a legislative determination that the public convenience and necessity did not require a curtailment of existing service, but only a regulation and limitation of future service. Some statutes do not, however, make such a provision. They are not for this reason unconstitutional. . $^{\text {t5 }}$

The certificates issued as a matter of right confer no superior rights; their holders are subject to the same obligations as other certificate holders. The right of operation granted by them is limited to the existing route..$^{70}$ Any change in route or addition to service must be obtained through the usual procedure."

It has been held that the right to a "grand-father clause" certificate is personal in nature to the extent of being issuable alone to the identical individual operating in good faith on the date set by the legislature. It is not issuable to a partnership or corporation formed by the original operator. ${ }^{78}$ But the courts

73 The following states provide for the issuance of a certificate as a matter of right, upon the filing of an application coupled with an afidavit setting out the fact of prior operation upon a date certain. Calif. Gen. Laws (Deering, 1923) § 5; Ind. Laws 1925, c. 46, § 2; Kan. Lavs 1925, c. $206, \S 11 ; \mathrm{Ky}$. Act of Mrarch 5, 1926, $\$ 7$; La. Act of July 15, 1920, $\$$; Mass. Acts 1925, c. 280, $\$ 4$; Minn. Laws 1925, c. 185, § 10; Nev. Laws 1925, c. $161, \S 3 ;$ N. J. Laws 1921 , c. 149 , at $390 ; 1$ Ohio Code (Page, 1926) \& 614-87; S. C. Acts 1925, No. 170 , § 3; S. D. Laws 1925, c. 224 , § 14; Va. Acts 1923, c. 161, § 3; Va. Acts 1924, c. 222, § 3; Wash. Laws 1921, c. 111.

74 Gruber v. Commonwealth, 140 Va. 312, 125 S. E. 427 (1924); Sheets Taxicab Co. v. Commonwealth, 140 Va. 325, 125 S. E. 431 (1924).

75 Motor Transit Co. v. Railroad Comm., 189 Calif. 573, 209 Pac. 586 (1922). The California statute now includes such a so-called "grandfather clause"; see Calif. Gen. Laws (Deering, 1923) Act 5120, \$ 5. Cf.

People v. Hadley, 66 Calif. App. 370, 226 Pac. 836 (1924).

is Sheets Taxicab Co. v. Commonwealth, supra note 74.

77 Motor Transit Co. v. Railroad Comm., supra note 75 (stopping at intermediate points en route).

78 Westhoven v. Public Utilities Comm., 112 Ohio St. 411, 147 N. E. 759 (1925); Re Westmoreland, Pub. Util. Rep. 1918 C 318 (Calif. 1918); Red Ball Transit Co. v. Public Utilities Comm., 112 Ohio St. 462,147 N. E. 762 (1925). 
of Virginia have held otherwise, upon broad grounds of principle. ${ }^{79}$

Statutes frequently provide that no certificate shall be granted by the commission until certain conditions have been met, such as the filing of indemnity bonds or insurance, incorporation of the carrier, the consent of the municipalities upon the route, and like conditions..$^{80}$ Of course, until such conditions have been met, no valid certificate can be issued. ${ }^{81}$

Assuming, however, that an application for a certificate is filed with a commission; that all preliminary conditions have been satisfied; and that the applicant is not entitled to a certificate as a matter of right, by what standard is the commission to determine whether the public convenience and necessity will

\footnotetext{
79 They have said that the reasoning behind allowing existing carriers to operate was that existing service did not crowd the roads and could be maintained without injury to the public or the carrier. It makes no difforence to the public if the individual operating takes on new associates. Besides, if the certificate were granted it would be impossible to provent the individual from forming indirect associations to effect his purposo. Carroll v. Commonwealth, 140 Va. 305,125 S. E. 433 (1924); Bowman v. Commonwealth, 140 Va. 299, 125 S. E. 435 (1924).
}

Under either one of these lines of decisions, the person engaged in prior operation must be an applicant or associated with the applicant.

80 Bonds or indemnity insurance are required by the following statutes: Ariz. Laws 1919, c. 130, \& 7; Conn. Pub. Acts 1921, c. 340; Idaho Laws 1925, c. 197, § 3; Ill. Rev. Stat. (Cahill, 1923) c. 111a, \$\$ 72, 73, 74, c. 95a, $\S \S 44-47$; Ind. Laws 1925, c. 46, § 3; Iowa Acts 1925, c. 5, § 12; Kan. Laws 1925, c. 206, § 7; Ky. Act of March 5, 1926, § 38a; La. Act of July 15, 1926, $\S 6$; Me. Laws 1925, c. $167, \S 14$; Mass. Gen. Laws (1921) c. $159, \S 46$, as amended by Mass. Acts 1925, c. 346, § 7; Mich. Pub. Acts 1923, No. 209, § 7; Minn. Laws 1925, c. 185, § 11; Miss. Laws 1926, c. 128, \$11; Mont. Laws 1923 , c. $154, \S 6$; Nev. Laws 1925 , c. 161 , § 2 ; N. H. Laws 1919 , c. $86, \S 2$; N. J. Laws 1926, c. $144, \S 3$, c. $231, \S 2 ;$ N. Y. Cons. Laws (Cahill, 1025 Supp.) c. $27, \S 282 \mathrm{~b} ; \mathrm{N}$. Y. Cons. Laws (Cahill, 1923) c. 64, $\$ 26$; N. C. Laws 1925 , c. $50, \S 3$ (g); N. D. Laws 1925 , c. $91, \S 0$; 1 Ohio Gen. Code (Page, 1926) \& 614-99; Okla. Laws 1923, c. 113, \& 7; Okla. Laws (Spec. Sess.) 1924, c. 105; Or. Laws (Spec. Sess.) 1921, c. 10, $\S 6$; Or. Laws 1921, c. 402; R. I. Gen. Laws 1923, $\S \S 3734,3735$; S. C. Acts 1925 , No. 170, $\S \S 5,18$; S. D. Laws 1925, c. $224, \S \S 15,16$; Utah Laws 1925, c. 114; Vt. Pub. Acts 1925, No. 73, at 113, No. 72, at 112; Va. Laws 1924, c. 222, § 4; Wash. Laws 1921, c. 111, § 5; W. Va. Ann. Code (Barnes, 1925) c. $43, \S 82$; Wis. Stats. $1925, \S 194.02$ (3).

As to local consent, see supra note 65 .

81 Not infrequently there is a specific legislative direction making rolevant the character of the applicant and his ability, financial or otherwise, to render the best kind of service. See Iowa Laws 1925, c. 5, \& 5 (applicant must show financial ability to carry out the service proposed); Kan. Laws 1925 , c. $206, \S 4$ (whether permanent or all-year-round a factor) ; La. Act of July 15, 1926, \& 3 (financial ability and good faith to be considered); Minn. Laws 1925 , c. $185, \S \&$ (permanency a factor); Miss. Laws 1926, c. $128, \S 8$ (permanency and continuity are to be considered); S. D. Laws 1925 , c. $224, \S 10$ (continuity a factor), § 14 (financial capacity a factor); Wyo. Comp. Stat. (1920) §5497 (financial ability a factor). 
be best served by granting or denying the application?:s Is the public interest served by competition between the new agency and the old regime-the rail carriers by steam or electricity? Is it in the public interest to allow competition between motor carriers? Is the "public," whose convenience and needs are in question, the individuals immediately concerned along the proposed route, or is the public at large meant? When is additional transportation a "convenience"? Is it a "necessity" when other agencies are available? These and similar problems have been perplexing the commissions and reviewing courts.

Whether competition between public carrier's best serves the public need for continuous, efficient and economical transportation, is at bottom a question of public policy; it is appropriate that the legislature formulate that policy in the motor carrier

82 The vital meaning of the phrase "public convenience and ncecsity" must, of course, be sought in concrete applications of the test by courts and commissions. The following effort at definition, from Wabash Ry. v. Commerce Comm., 309 IIl. 412, 418, 141 N. E. 212, 214 (1923) is, however, not without interest:

"When the statute requires a certificate of public convenience and necessity as a prerequisite to the construction or extension of any public utility, the word 'necessity' is not used in its lexicographical sense of 'indispensably requisite.' If it were, no certificate of public convenicnce and necessity could ever be granted. The first telephone was not a public necessity under such a definition, nor was the first electric light. Even the construction of a waterworks system in a village is seldom necescary though highly desirable. However, any improvement which is highly important to the public convenience and desirable for the public welfare may be regarded as necessary. If it is of sufficient importance to warrant the expense of making it, it is a public necessity. (Parle and Boulcrard Conzs. v. Moesta, 91 Mich. 149.) A thing which is expedient is a necessity. (Warden v. Madisonville, Henderson and Evansville Railroad Co. $128 \mathrm{Kg} .563$. Inconvenience may be so great as to amount to necessity. (Lototon 2 . Rives, 2 IIcCore L. 445.) A strong or urgent reason why a thing should be done creates a necessity for doing it. (Todd v. Floumcy, 50 Ala. 99.) The word connotes different degrees of necessity. It sometimes means indispensable; at others needful, requisite or conducive. It is relative rather than absolute. No definition can be given that would fit all statutes. The meaning must be ascertained by reference to the context and to the objcets and purposes of the statute in which it is found. (Wisconsin Telcphone Co. v. Railroad Com. 162 Wis. 383.) The Commerce Commission has a right to, and should, look to the future as well as to the present situation. Public utilities are expected to provide for the public nceessities not only to-day but to anticipate for all future developments reasonably to be foreseen. The necessity to be provided for is not only the existing urgent need but the need to be expected in the future, so far as it may be anticipated from the development of the community, the growth of industry, the increase in wealth and population and all the elements to be expceted in the progress of a community."

See also the famous discussion of the constitutional phrase "ncesscary and proper" by Chief Justice MIarshall in MeCulloch v. Miaryland, 1 Whcat. 316,413 (U. S. 1819). 
statutes..$^{85}$ In some of the more recent statutes such formulation has been explicit and in considerable detail $;^{84}$ in other states the commission or reviewing courts have been able to spell out what policy was intended by the legislature by a construction of the whole public utility act; ${ }^{55}$ in others, the legislatures have thrown the commissions upon their own responsibility.

A reading of these statutes is enough to convince one that the day when vigorous competition between public utilities was thought to further the public interest has gone. For example, in the North Dakota Motor Carrier Act of 1925 it is provided that in passing upon an application for a certificate the "Commission shall give reasonable consideration to the transportation service being furnished or that could be furnished by any railroad, and the effect which such proposed transportation service may have upon other forms of transportation service which are essential and indispensable to the communities to be affected by such proposed transportation service, or that might be affected thereby, and to the traffic already existing upon the route proposed to be traveled. . . . The Commission shall avoid as far as possible, consistent with the public interest, the duplication of transportation service." Similar, though more concise directions, requiring the commissions to consider all existing transportation services in deliberating upon an application, are to be found in the statutes of Kansas, Ohio, South Dakota, Wyoming, Kentucky, Colorado and West Virginia. ${ }^{80}$ The Virginia statute, on the other hand, denies the commission the right to refuse a certificate to class A carriers simply because of "the existence of a railroad or other motor vehicle carriers in the territory sought to be served," although it may be considered as "a good cause for limiting the number of vehicles which

${ }^{83}$ See Lilienthal, The Power of Governmental Agencies to Compel Testimony (1926) 39 HARv. L. Rev. 694, 723 and notes 106, 107.

84 See infra notes 85-90.

85 The Illinois statute contains no specific legislative declaration upon this matter, unless it be the statement in $\S 55$ that "no certificate . . . shall be construed as granting a monopoly or an exclusive . . . franchise." In setting aside an order granting a certificate to a bus line competing with a street railway, the Illinois Supreme Court said:

"It is not the policy of the Public Utilities Act to promote compotition between common carriers as a means of providing service to the public. The policy established by that act is that, through regulation of an established carrier occupying a given field and protecting it from compotition it may be able to serve the public more efficiently and at a more reasonablo rate than would be the case if other competing lines were authorized to serve the public in the same territory." West Suburban Transportation Co. v. Chicago \& W. T. Ry., 309 Ill. 87, 91, 140 N. E. 56, 58 (1923).

$86 \mathrm{Kan}$. Laws 1925, c. 206, $\$ 4$; 1 Ohio Code (Page, 1926) $\S 614-87$; S. D. Laws 1925, c. 224, § 3; Wyo. Comp. Stat. (1920) \& 5497; Ky. Act of March 5, 1926, § 4; Colo. Ann. Stat. (Courtright's Mill's, 1924) § 5933i (a); W. Va. Ann. Code (Barnes, 1925) c. $43, \S 82$. 
such applicant may operate on the route." As to class B carriers, the commission may not consider other transportation agencies in the territory in any manner..$^{\mathrm{sz}}$ And if an applicant otherwise meets the standards of public good laid down by the law, the Wisconsin commission must issue a certificate to him, "regardless of any other service furnished." 88 A similar provision is in the South Carolina Act of 1925. ${ }^{80}$ In both Montana and North Dakota the commission is to give full consideration to other transportation agencies, but a cautionary word that a certificate is not to be deemed to establish a monopoly has been inserted by legislatures who have behind them a tradition which favors competition and frowns upon exclusive grants to public utilities. $^{90}$

The decisions of the commissions and courts seem, on the whole, consistent with such enactments, and in truth, with the theory of all latter-day public utility regulation. Commissions generally have sought to avoid duplication of service, with its consequent economic waste; their first inquiry, even when not so required by the statute under which they act, has been: is the transportation service now rendered in the territory sought to be served by this new motor carrier adequate to the needs of that territory? If it is adequate, they have decided against permitting a competitor to enter the field, with resulting duplication and impairment of the existing agency's ability to render satisfactory service at a low rate. ${ }^{01}$ In considering whether the service is adequate they have taken into consideration all forms

${ }^{87} \mathrm{Va}$. Acts 1924 , c. $222, \S 3$.

88 Wis. Stat. 1925, $\S 194.02$.

s9 S. C. Acts 1925, No. 170, $\$ 4$.

90 Mont. Laws 1923 , c. $154, \S 4$; N. D. Laws 1925 , c. $91, \S \S 4,5,8$.

91 The following illustrative decisions of commissions throughout the country contain discussions upon this point: Re Automobile Trafic, Pub. Util. Rep. 1915 C 945, 952, 953 (Ariz. 1915) ; Re Bohn, Pub. Util. Rep. 1918 B 288, 291 (Ariz. 1917); Re International Auto Stage Line, Pub. Util. Rep. 1925 A 428, 430 (Ariz. 1924); Re Niotor Transit Company, Pub. Util. Rep. 1922 D 495, 504 (Calif. 1922); Re United Stages, Pub. Util. Rep. 1925 A 688, 696 (Calif. 1924); Re City of Bridgeport, Pub. Util. Rep. 1922 B 193 (Conn. 1921); Re People's Motor Bus Company, Pub. Util. Rep. 1918 C 903, 904 (III. 1918); Re Kipp's Express Co., Pub. Util. Rep. 1923 E 250, 256 (Ill. 1923); Re Miaine MIotor Coaches, Inc., Pub. Util. Rep. 1926 B 545 (MTe. 1925); Re Dean, Pub. Util. Rep. 1920 C 972, 974 (Mid. 1920); Re Anderson Bros., Pub. Util. Rep. 1922 D 750, 754 (Nev. 1922); Re Blevins, Pub. Util. Rep. 1919 F 58, 62 (N. Y. 1919); Re Bingaman Motor Express Company, Pub. Util. Rep. 1924 C 389, 392, 393 (Pa. 1924); Re Flaugh, Pub. Util. Rep. 1924 D 862, 863 (Pa. 1924); Re Application to Operate Jitneys, Pub. Util. Rep. 1922 E 612, 617 (R. I. 1922); Re Streeper, Pub. Util. Rep. 1924 B 392 (Utah, 1923); Re Jewett \& Son, Pub. Util. Rep. 1924 A 155 (Vt. 1923); Re Washington Rapid Transit Co., Pub. Util. Rep. 1923 B 328 (Wash. 1922); Re Jossey, Pub. Util. Rep. 1924 B 420, 425 (Wash. 1924). 
of transportation, including steam and electric railway and other motor carriers..$^{22}$ Such a view seems sound, particularly in the light of recent salutary efforts to co-ordinate motor and rail transportation into a unit, with each facility rendering the service most appropriate to it. ${ }^{93}$

But if existing service, whether by rail or motor, is shown to be inadequate and unsatisfactory, or even if the riding public shows a definite preference for motor over rail service ${ }^{04}$ then the public convenience and necessity requires that the application be granted, even if the result is to cause great financial injury to existing and long-established carriers, whose plants represent

92 See, for examples, McLain v. Public Utilities Comm., 110 Ohio St. 1, $12-13,143$ N. E. 381,384 (1924); Allegheny Valley Street Railway v. Greco, Pub. Util. Rep. 1917 A 723 (Pa. 1916); Petition of Gray, Pub. Util. Rep. 1916 A 33 (N. Y. 1915); Re Wilson \& Co., Pub. Util. Rep. 1020 C 635 (Calif. 1920); Re Motor Transit Co., Pub. Util. Rep. 1922 D 495 (Calif. 1922); Re North River Transportation Co., Pub. Util. Rep. 1925 D 812 (Wash. 1925); Eager v. Public Utilities Comm., 113 Ohio St. 604, 149 N. E. 865 (1925) ; Cincinnati Traction Co. v. Public Utilities Comm., 112 Ohio St. 699, 148 N. E. 921 (1925). See also the valuable note in (1926) 24 MiCH. L. REv. 393; Slater, The Motor Bus as a Competitor of the Railroads (1926) 2 Journal of LaND \& Public Utulity Economics, 129. Comparo Rapid Railway v. Michigan Public Utilities Comm., 225 Mich. 425, 196 N. W. 518 (1923), in which the Michigan Supreme Court held that tho commission is limited in its inquiry concerning the extent of other transportation facilities, to motor-vehicle rivals. Fellows, J., dissented in a strong opinion which represents the general law.

${ }^{93}$ See supra note 2. Note also such cases as Application of Illinois Powor \& Light Corporation, 4 IIl. Commerce Comm. 40, 41 (1924); Illinois Commerce Comm. v. Zeda, Pub. Util. Rep. $1923 \mathrm{E} \mathrm{250,256}$ (Ill. 1923); Washington Ry. v. Washington Rapid Transit Co., Pub. Util. Rep. 1922 D 754 (D. C. 1922) ; Re Wyoming Valley Auto-Bus Co., Pub. Util. Rep. 1925 D 332 (Pa. 1925). See Ritchie, Co-ordination of Rail and Automobile Transportation (1926) 67 MCGRaW Electric RaIlway MIANUAL, 201; Reeves, Co-ordination of Electric Railway and Bus Transportation (Nov. 1923) AERA; Williams, The Motor Bus as an Adjunct to the Railroud (1923) 75 RAIIWAY AGE, 1199; Emery, Buses or Railroad-or Both (Sept. 1926) AM. Review of Reviews. On February 27, 1926 the magazine RALwW AGE inaugurated a Motor Transport Department. See the interesting dissent of Chairman Atwill in Re New York, N. H. \& H. R. R., Pub. Util. Rep. 1026 D 161, 163 (Mass. 1926).

${ }^{84}$ In Re Troy Auto Car Company, Pub. Util. Rep. 1917 A 700, 704 (N. Y. 1926) the commission said: "It would seem, furthermore, that tho number of cars operated by the traction company in the competitive district is sufficient to carry the traffic, and it would seem a priori that the streot car operation on a headway varying from five minutes to less than two minutes would invite passengers away from automobile transportation on a headway of fifteen minutes. . . . In spite of this theoretical consideration, the fact confronts us that during fifteen months' operation of the stage route its buses carried 770,852 passengers. This is an absolute demonstration that many people of the neighborhood concerned regard the stage route as a superior convenience."

See also Petition of Gray, Pub. Util. Rep. 1916 A 33 (N. Y. 1915). 
great investments. The commissions and courts can go so far in atternpting to prevent duplication and conserve existing foeilities, that the entrepreneurs in the bus field will be forced out, and the demand for the special lind of service they can furmish be unjustly denied. If American transportation history can serve as a guide, there should at first be considerable freedom given to any new agency struggling to find a place in the generol system of transport.95

95 Blakeslee, C., in Re Aldrich, Pub. Util. Rcp. 1929 A 895,800 (iv. Y. 1922) : "It is said that when the Erie Canal was projected, it was strcauously opposed by those who hauled freight by ox-teams from Albany wostward, because the canal competition threatened to destroy their establichod business. When the first crude locomotive began to draw pasconger and freight cars, it undoubtedly meant ruinous compctition to the lincs of stage coaches. . . But . . . the competition of the established carrier had to yield to a more adequate and convenient method of transportation."

The stage route companies, and turnpike and canal interests vigorously opposed the building of railroads. See NIEIER NND MILGIL, HISTORY of TRansfortation IN THE UNITED States BeFore 1860 (1917) 317, 313; CaRter, When Ramroads Were NEW (1909) 27, 28, 181; and see the report of the Pennsylvania Board of Canal Commissioners of Deccmber, 1831. On popular opposition to railroads, see Hill, Bcginning of Boston and Worcester Raütroad (1902) Procendngs of THE WORCESTER Sociery of ANTieUTy 1901, 527, 543; Lamb, Glimpses of The Railiogd in History (1891) 25 ILAGaZINE OF AMIERICAN HisTORY, 430, 442.

The stand of the Illinois Supreme Court in the very recent case of Egyptian Transportation Co. v. Louisville \& Nashville Ry., supra note 15, seems unsound. There the commission had found that a certain territory required frequent service, and that this the rail carriers had not been furnishing. There was evidence that the only economical way in which the required service could be rendered was by motor bus, and that the railroad was not operating busses. The commission accordingly mont $d$ a crificate to a reputable bus company. The Supreme Court set this order aside, holding that (p. 588) "it is the established policy of the law in this State that a public utility be allowed to earn a fair return on its investments. It is therefore not only unjust but poor economy to grant to a much less responsible utility company the right to compete for the business of carrying passengers by paralleling its line unless it appears that the necessary service cannot be furnished by such railroad." In other words, even where service by rail is inadequate, and there is need for motor carriers, independent bus lines must not enter, if the railroads wish to epsrate bis themselves.

The view generally held, however, is that expressed by the Superior Court of Pennsylvania, in Pottsville Union Traction Co. v. Public Service Comm., $67 \mathrm{~Pa}$. Super. Ct. 301, 304 (1917) where the court said: "The primary object of the public service laws is not to establish a monopoly or guarantee the security of investment in public service corporations, but first and at all time in the just exercise of its powers to serve the interests of the public."

And in Re Colorado Motor Way, Inc., Pub. Util. Rep. 1924 A 56, 61 (Colo. 1923) the Colorado Commission said:

"It would seem to be time for railroad companies to understand that the state does not guarantee a satisfactory return upon utility investments, 
A different problem arises when two or more motor carriers apply for a single territory, where it is clear that one certificate should be issued. The question becomes not one of determining the effect of competition, but of deciding which applicant is more likely to render the better service. The financial ability of the applicants must be considered, under some statutes, and even without such a provision the experience and reliability of the operators will be considered. ${ }^{96}$ Very recently the existing rail carriers have gone into the motor carrier business upon a large scale, either directly or through subsidiaries; ${ }^{07}$ the same weighing of advantages will take place when such a carrier seeks a certificate in competition with a motor company applicant. In Re Wyoming Valley Auto-Bus Company, ${ }^{\circ 8}$ the Pennsylvania public service commission held that as between an independent bus line and a bus subsidiary, auxiliary to a street railway corporation, the latter would be preferred. The commission stated that the benefits of co-ordinated service available through the subsidiary, and its superior financial resources were important considerations. The Washington Department of Public Works

and further that the automobile is here to stay and that it cannot bo eliminated by any Utility Commission nor by any court or legislature; that it is a great industrial fact and must be met and treated as such."

See also Re Aldrich, supra at 390, where it was said:

"This is a period of transition and to require those living at a distance from fixed railroad stations to journey to the stations and there await the arrival of trains, rather than to be allowed to take advantage of buses stopping at their front doors, merely because this would result in financial loss to the established carrier (the railroad), is not in keeping with ideas of progress."

See also Re Demoney, Pub. Util. Rep. 1920 C 402, 404; Re Railrond Broadhead, Pub. Util. Rep. 1924 E 222, 223 (Mont. 1924); Re Carvor, Pub. Util. Rep. 1923 B 242, 247 (Colo. 1922).

${ }^{96}$ The following cases which have been passed upon by the Ohio and Illinois commissions serve to illustrate the diversity of problems which confront the commissions throughout the country where more than one motor carrier applies for the same route: In re Application of Merryman (1924) Ohio Pub. Util. Comm. 47; In re Cadillac Bus Co., ibid. 56; In re Ackley, ibid. 57; In re Norwalk Bus Co., ibid. 48; In re Cullison (1925) ibid. Nos. 923, 1032, 22 D. R. 202; In re Pickens (1926) ibid. Nos. 1917, 2068, 2047, 24 D. R. 351; Application of Peoria Coach Line, 4 Ill. Commerce Comm. 32 (1924); Application of City Motor Bus Co., ibid. 50 (1924).

97 For examples: The New England Transportation Co., a subsidiary of the New York, New Haven and Hartford Railroad, was operating 125 busses over nearly 800 miles on January 1, 1926; the Public Servico Transportation Co., a New Jersey electric railway, was operating ovor 800 busses over 90 routes; 51 steam railroads were using motor trucks to supplement their shipping service. Since the date of.tabulation, use of motor vehicles by railroads has been increasing at an amazingly rapid rate. The Baltimore and Ohio Railroad has, within the past few months, ceased to maintain a New York City terminal, and now transports its passengers to and from its Jersey City station by motor busses.

98 Pub. Util. Rep. 1925 D 332 (Pa. 1925). 
preferred a resort development company over an independent bus line, in granting a certificate to operate over a new road to the gate-way of the resort. This order the Supreme Court reversed, upon appeal, holding that the statute made it mandatory upon the commission to grant the certificate to the bus line, because it had been operating in the territory prior to the opening of the resort.99

The task of the commissions in controlling the competitive situation has been made easier by common provisions authorizing them not simply to grant an application or deny it, but to grant the application in part only, or grant it upon conditions. This has given administrative flexibility to the commissions without which their work would be seriously hampered.

\section{REVOCATION OR ALTERATION OF CERTIFICATES}

All the recent enactments requiring certificates, and most of the commission regulations promulgated under general or special statutes, empower the commissions to revoke or alter certificates of public convenience and necessity. The grounds for revocation vary. In some states the commission can only revole for a violation of orders or rules of the commission or those laid down by the regulatory statute. ${ }^{100}$ Since the rules of the commission often cover the most minute details of operation, under such statutes a certificate may be revoked for such comparatively minor infractions as failure to stop at railroad crossings, ${ }^{101}$ or failure to maintain an operating schedule for three days. ${ }^{102}$ Where the causes for revocation are set out in the Act, it has been held that the commission is without power to revoke for other causes. ${ }^{103}$

In other states, however, commissions have the same discretion in withdrawing certificates, even when action has been

99 Yelton \& MrcLaughlin v. Department of Public Works, 136 Wash. 445, 240 Pac. 679 (1925) reversing Re Mount Baker Development Co., Pub. Uxil. Rep. 1925 D 705 (Wash. 1925).

${ }_{100}$ Idaho Laws 1925, c. 197, § 4; Ky. Act of March 5, 1926, § 13; Md. Ann. Code (Bagby, 1924) art. 56, $\$ \S 255,262$; Mich. Pub. Acts 192\%, No. 209, § 6; Miont. Laws 1923, c. 154, § 5; N. J. Laws 1926, c. 144, 33 (of local consent) ; N. D. Laws 1925, c. $91, \S 4$; S. C. Acts 1925 , No. 170, $\$ 12$ (grounds specified and exclusive); Va. Laws 1924, c. 222, $\$ 3$ (grounds specified and exclusive); Wash. Laws 1921, c. 111, $\$ 3$; W. Va. Code (Barnes, 1925) c. $43, \S 82$. See State v. Fortney, 93 W. Va. 292, 116 S. E. 753 (1923) ; but cf. State v. State Road Comm., 131 S. E. 7 (W. Va. 1025). 101 Re automobiles at crossings, Ariz. Corp. Comm., General Order No. 5, January 15, 1926; Rules and Regulations, Or. Pub. Serv. Comm. Order F, 1297 , rule 13.

102 Rules governing motor vehicles, Me. Pub. Util. Comm., July 9, 1921. ${ }^{103}$ State v. Fortney, supra note 100. But cf. rale 54, State Road Comm. of West Virginia, and State v. State Road Comm., supra note 100. 
taken by the holder in reliance thereon, as they have in the granting of such certificates. The phrase commonly used in the Acts is "for good cause" or "for such other cause as the said Commission may deem sufficient." 104 The courts have sustained revocations when there is fraud or mistake in the issuance of certificates, and where service has been abandoned. ${ }^{105}$

Most of the statutes providing for revocation protect the holder by requiring ample notice and opportunity to be heard before such revocation or alteration. ${ }^{106}$ In some states an opportunity is given, after the close of the revocation hearing, to make the service satisfactory before the certificate is granted to another. ${ }^{107}$

\section{APPEAL AND REVIEW OF COMMISSION ORDERS}

A commission order granting or denying a certificate of con-

104 See Calif. Gen. Laws (Deering, 1923) Act 5129, § 5 ("for good cause") ; Iowa Acts 1925, c. 5, § 17; Kan. Laws 1925, c. 206, § 8 ("for good cause"); La. Act of July 15, 1926, $\$ 4$ ("for good cause"); Ohio Code (Page, 1926) § 614-87 ("for a good cause"); Okla. Laws 1923, c. 113. § 4; Or. Laws (Spec. Sess.) 1921, c. 10, § 5 ("or for such other cause as the said Commission may deem sufficient").

See also abstract of Emerick Bus Line Co. v. Bellefonte Transportation Co., Pub. Util. Rep. 1920 E. 380 (Pa. 1919). It has been held that revocation is the exercise of a discretionary power, hence mandamus is not available. State v. State Road Comm., supra note 100.

105 Reynolds v. Alexandria Motor Bus Line, 126 S. E. 201 (Va. 1925) and see Calistoga Stage Line v. White Transportation Co., Pub. Util. Rep. 1918 E 821 (Calif. 1918); but cf. abstract of Re Swett, Pub. Util. Rep. 1921 C 637 (Calif. 1921).

The following decisions by the Ohio Public Utilities Commission upon problems of revocation in the motor carrier field illustrate many of tho types of cases which commissions in the various states have now or will have presented to them for their administrative judgment: $R_{\theta}$ Youngstown v. Hogan (1924) Ohio Pub. Util. Comm. 60; Re Conch, Jx., ibid. 41; Stewart v. Westhoven, ibid. 149, aff'd in Westhoven v. Public Utilities Comm., 112 Ohio St. 411, 147 N. E. 759 (1925); Dayton \& Western Truiction Co. v. Red Star Transportation Line (1924) Ohio Pub. Util. Comm. 117; Seals Bus Line v. Zupfel Bus Line, ibid. 109; Vasbinder v. Senville, ibid. 115; Shields v. Moore (1925) ibid., 22 D. R. 295; Application of the Northern Ohio Traction Co., ibid., 22 D. R. 440; Powell v. Coombs, ibid., 21 D. R. 373; Cincinnati Traction Co. v. Carley, ibid., 22 D. R. 234; Shafor v. Schelling, ibid., 21 D. R. 460; Matter of Long, ibid., 21 D. R. 350; Southern Ohio R. S. Co. v. Danniells, ibid., 22 D. R. 30.

${ }^{106}$ E.g. Calif. Gen. Laws (Deering, 1923) Act 5129, \& 5; Kan. Laws 1025, c. 206, § 8; Ky. Act. of March 5, 1926, § 13; La. Act. of July 15, 1926, § 4; Mich. Pub. Acts 1923, No. 209, § 6; Minn. Laws 1925, c. 185, § 4; Miss. Laws 1926, c. $128, \S 5$; Mont. Laws 1923, c. 154 , § 5; N. J. Laws 1926, c. 144, § 3; N. C. Laws 1925 , c. 50 , § 5; N. D. Laws 1925 , c. 91 , \& 4; Okla. Laws 1923 , c. $113, \S 4$; Or. Laws (Spec. Sess.) 1921, c. 10, § 5; Wash. Comp. Stat. (Remington, 1922) § 6389.

107 E. g. Ohio Code (Page, 1926) § 614-87; La. Act of July 15, 1926, No. $292, \S 4$. This seems also to be the practice of some commissions; e. g. (in another field) see Odin v. Odin Coal Co., 4 Ill. Commerce Comm. 276 (1925). 
venience and necessity, or revoling or altering such a certificate, may be reviewed in the courts; the statutes almost without exception so provide, ${ }^{108}$ and even where there is no such express provision, it has been held that the right exists. ${ }^{203}$

The general constitutional principles which make access to the courts necessary for those aggrieved by administrative orders apply of course to commission orders denying or granting certificates to motor carriers. ${ }^{120}$ In determining whether such an order of the commission should stand or be set aside, the various supreme courts have applied the same limitation upon their reviewing function as in cases involving other commission orders in other fields. Some courts inquire into the weight of the evidence. ${ }^{111}$ The courts of other states reverse the order of the commission only if plainly unlawful or unsupported by evidence. ${ }^{122}$ In some situations some courts will go much fur-

Ins Examples of such statutes include Calif. Stat. 1925, c. 15\%, at 303; Colo. Comp. Laws (1921) $\$ \S ~ 2960,2961$; Conn. Pub. Acts 1921, c. 77, § 7; D. C. Ann. Code 1924, Appendix, Pub. Util. par. 65; II. Rev. Stat. (Cahill, 1923) c. 111a, $\S ~ 74,87,88,90$; 4 Ind. Ann. Stat. (Burns, 1914) \$§. 10052z2-10052e3; Iowa Acts 1925, c. 5, § 10; Ky. Act of March 5, 1926, §§ 12, 13, 16, 17, 18; Md. Ann. Code (Bagby, 1924) art. 25, 350 ; Mich. Comp. Laws (Cahill, 1922) § 8164 (9), and Laws 1923, No. 209, §§ 4, 5; Minn. Laws 1925, c. 185, \$12; Mont. Laws 1923, c. 154, \$7; Neb. Comp. Stat. (1922) §5499; Nev. Laws 1923, c. 181, § 9; N. Y. Laws 1918, c. 130, at 305 ; N. C. Laws 1925 , c. $50, \S 5$; N. D. Laws 1925 , c. 91 , 10 ; Or. Laws (Spec. Sess.) 1921, c. 10, § 7; Pa. Stat. (West, 1920) $\$ \S 18178,18102$; R. I. Gen. Laws 1923, § 3730; S. C. Acts 1925, No. 170, $\$ 12$; S. D. Laws 1925, c. 224, $\S 18$; Utah Comp. Laws (1917) $\S \S 4834-4837$; Vt. Laws 1025, No. 74, § 6; Va. Gen. Laws (1923) § 3734; Va. Laws 1924, c. 222, § 3; Wis. Stat. 1925, §§ 194.04, 196.42, 196.47; Wash. Laws 1921, c. 111, § 6; Wyo. Comp. Stat. (1920) $\$ \S 5511-5516$.

${ }_{109}$ Ex parte Sales, 108 Okla. 29, 233 Pac. 186 (1925).

${ }^{110}$ See Albertsworth, Judicial Review of Administrative Aetion by The Federal Supreme Court (1922) 35 HARv. L. Rev. 127; Curtis, Judicial Review of Commission (1921) 34 HARv. L. REv. 862.

111 The Mlinois cases are good illustrations of this standard. See Egyptian Transportation Co. v. Louisville \& Nashville Ry., supra note 15 (commission order granting certificate to bus line paralleling steam railroad set aside) ; Superior MIotor Bus Co. v. Community MIotor Bus Co., $320 \mathrm{Il}$. 175,150 N. E. 668 (1926) (2 bus applicants; commirsion order set aside) ; Choate v. Commerce Comm., supra note 6 (commission found existing service required supplementation; order set aside); West Suburban T. Co. v. Chicago \& W. T. Ry., 309 Ill. 87, 140 N. E. 56 (1923) (commission found existing public need; order set aside); Chicago Motor Bus Co. v. Chicago Stage Co., 287 IIl. 320, 122 N. E. 477 (1919) (two motor applicants; commission order set aside).

In Indiana, in an action to set aside an order of the commission, the lower court must hear the evidence de novo. Public Service Comm. v. Lake Erie \& W. Ry., 191 Ind. 436, 133 N. E. 492 (1922).

112 See Gruber v. Commonwealth, supra note 74, at 318, 125 S. E. at 428 ; Carroll v. Commonwealth, supra note 79; Royal Green Coach Co. v. Public Utilities Comm., 110 Ohio St. 41, 143 N. E. 547 (1924) ; State v. Depart- 
ther; in effect they regard the decision of the commission on such a question as the choice between applicants as final, and set it aside only in the rare case where there is no evidence at all to support the finding, where the procedural requirements imbedded in due process of law have not been observed, the plain provisions of the statute ignored, or the commission's discretion abused. ${ }^{213}$

\section{ENFORCEMENT OF CERTIFICATES}

The task of enforcing the legal situation which the issuance of certificates of convenience and necessity creates, is a dual one. First of all, the holder of a certificate must be required to comply with the conditions embodied within the certificate itself; the provisions of the public utility and other applicable statutes, and general commission regulations must be enforced against him. The second problem of enforcement is to prevent operation by non-holders, operators who properly come within the class from which certificates are demanded, but to whom such certificates have never been granted.

The statutes usually specifically provide for the certificate holder who violates the provisions of his certificate, the statutes, or the rulings of the commission. A penalty, either by fine, or both fine and imprisonment, is usual $;^{114}$ his certificate may be revoked;115 the commission is frequently specifically empowered to resort to injunction or mandamus to enforce its orders. ${ }^{110}$

ment of Public Works, 129 Wash. 5, 223 Pac. 1048 (1924); In re Stoltingr 131 Wash. 392, 230 Pac. 405 (1924); Gongaware v. Public Service Comm., 83 Pa. Super. Ct. 269 (1924); State v. Darazzo, 97 Conn. 728, 118 Atl. 81 (1922); Holmes v. Railroad Comm., 242 Pac. 486, 490 (Calif. 1925).

113 See Modeste v. Public Utilities Comm., 97 Conn. 453, 458, 117 Atl. 494, 496 (1922); People v. Hadley, supra note 77; In re Samoset Co., 131 Atl. 692, 693 (Me. 1926) ; Royal Green Coach Co. v. Public Utilities Comm., supra note 112; cf. Chicago Bus Co. v. Chicago Stage Co., supra noto 111. 114 Colo. Comp. Laws (1921) § 2970 et seq; Conn. Pub. Acts 1921, c. 77, $\S 8$; D. C. Ann. Code (1924) Appendix, Pub. Util. par. 81-86; Idaho Laws 1925 , c. 1917 , § 7; Ind. Laws 1925 , c. $46, \S 8$; Iowa Acts 1925, c. $5, \S 18$; Kan. Laws 1925, c. 206, § 9; Ky. Act of March 5, 1926, § 39; Md. Ann. Code (Bagby, 1924) art. 56, $\S \S 256,263$, art 23, $\S 383$; Mass. Acts 1925, c. 280, § 3; Mich. Pub. Acts 1923, No. 209, § 9; Minn. Laws 1925, c. 185, $\S 13$; Miss. Laws 1926, c. $128, \S 18$; Mont. Laws 1923, c. 154, § 9; Nov. Laws 1925 , c. $161, \S 3$; N. J. Laws 1926 , c. $144, \S 5$; N. Y. Cons. Laws. (Cahill, 1923) c. $49, \S 57 ;$ N. C. Laws 1925 , c. $50, \S 11 ; 1$ Ohio Gen. Codo (Page, 1926) §§ 614-65, 614-68; Okla. Laws 1923, c. 113, § 10; Or. Laws (Spec. Sess.) 1921, c. 10, § 9; Pa. Stat. (West, 1920) \$\$ 18197, 18206 ; R. I. Gen. Laws 1923, § 3731; S. C. Acts 1925, No. 170, § 14; S. D. Laws 1925, c. 224 , § 22; Utah Comp. Stat. (1917) §§ 4839-4849; Vt. Laws 1925, No. 74, § 7; Va. Laws 1924, c. 222, § 8; Va. Laws 1923, § 3716; W. Va. Ann. Code (Barnes, 1925) c. $43, \S 82$; Wash. Laws 1921, c. 11, § 7; Wis. Stat. 1925, § 194.06; Wyo. Comp. Stat. (1920) §§ 5517-5528.

115 See supra, under "Revocation."

116 Colo. Gen. Laws (1921) § 2970; D. C. Ann. Code (1924) Appendix, 
The fact that the operator has already been prosecuted under the penalty provisions does not preclude use of other remedial means by the commission, the enforcement provisions being held cumulative, not exclusive. 117

A more difficult problem of enforcement is presented by the motor carrier operating illegally without a certificate of convenience. Such an operator may be a carrier whose certificate has been revoked, but who continues to operate in spite of the commission's orders; he may be one who has never applied for a certificate, claiming that he is not within the classes of carriers covered by the Act. In either case, his violation of the law affects not only the commission, which is usually under a duty to enforce the law; the effect is more serious upon the authorized operator along the same route, or upon an established rail carrier, in whose interests on behalf of the public need for sound transportation, the legislature provided for the issuance of certificates.

While most of the statutes are explicit enough in authorizing the commission, through the courts, to prosecute or enjoin such illegal operators, only a few authorize such action by certified operators suffering damage by such illegal operation. But the courts have not been slow in granting such relief on the suit of those showing damage to their interests. Loss of revenue to a street railroad is held to be sufficient "special damage" to entitle it to injunctive relief against unauthorized operation. ${ }^{119}$ It is not necessary that the injured party first complain to the commission, empowered to enforce the law; he may at once seek relief in a court of appropriate jurisdiction. ${ }^{112}$ The recognition

Pub. Util. par. 91; Ind. Laws 1925, c. 46, § 9; Kan. Rev. Stat. (1923) $\$ \S 66-139,66-181 ; 1$ MId. Ann. Code (Bagby, 1924) art. 23, $\S$ 385, art. 256, art 265; Miss. Gen. Laws (1921) c. 159 , $\$ \S 40$, 48; Miass. Acts 1925 , c. 280, § 3; Mich. Pub. Acts 1923, No. 209, § 10; N. J. Laws 1926, c. 144, $\S 5 ;$ N. Y. Cons. Laws (Cahill, 1923) c. 49, $\$ 57 ; 1$ Ohio Gen. Code (Page, 1926) $\$ 614-69$; Pa. Stat. (West, 1920) $\$ \S 18195$, 18196; S. D. Laws 1925, c. 224, $\$ 17$; Utah Comp. Stat. (1917) § 4842; Vt. Gen. Laws (1917) $\$ 5061$ (VI); Wyo. Comp. Stat. (1920) $\$ 5509$.

117 State v. State Road Comm., supra note 100; Public Utilities Commissioners v. Sheldon, 95 N. J. Eq. 408, 124 Atl. 65 (1924). It was held in People v. Carr, 231 Mich. 246, 203 N. W. 948 (1925) that prosecutions for illegal operation might be initiated by private individuals.

118 Puget Sound Traction Co. v. Grassmeyer, 102 Wash. 482, 173 Pac. 504 (1918) ; MTemphis Street Ry. v. Rapid Transit Co., 138 Tenn. 594, 179 S. W. 635 (1916).

119 People v. Watt, 115 MIisc. 120, 188 N. Y. Supp. 559 (Sup. Ct. 1921); Northern Pac. Ry. v. Schoenfeldt, 123 Wash. 579, 213 Pac. 26 (1023); State v. Superior Court, 123 Wash. 116, 212 Pac. 259 (1923); Danville, U. \& C. Ry. v. Clark Truck. Co., 231 Ill. App. 339 (1924); Huntington Traction Co. v. Walker, 209 App. Div. 904, 205 N. F. Supp. 894 (2d nept. 1921). And the fact that the operator committed a crime by failing to obtain a license 
of a property right which the law's remedies are inadequate to protect, but which equity is able to safeguard against interference, is one of the familiar aspects of the rapid development of the law in this new field. ${ }^{120}$

is no bar to injunctive relief. N. Y., N. H. \& H. Ry. v. Deister, 253 Mass. 178,148 N. E. 590 (1925).

${ }^{120}$ In the following illustrative cases the courts have granted relief to public utilities injured by the unauthorized operation of motor carriers: Chelan Transfer Co. v. Foote, 130 Wash. 511, 228 Pac. 297 (1924); Carson v. Woodram, 95 W. Va. 197, 120 S. E. 512 (1923); Puget Sound Traction Co. v. Grassmeyer, supra note 118; Northern Pacific Ry. v. Schoenfeldt, supra note 119; Danville Ry. v. Clark Truck Co., supra note 119; Pocnhontas Transportation Co. v. Craft, 130 S. E. 468 (W. Va. 1925); Newport Electric Corp. v. Oakley, 129 Atl. 613 (R. I. 1925); Darling v. Darling, 118 Misc. 817, 194 N. Y. Supp. 897 (Sup. Ct. 1922); Public Utilities Comm. v. Garviloch, 54 Utah, 406, 416, 181 Pac. 272, 276 (1919); United Traction Co. v. Smith, 115 Misc. 73, 187 N. Y. Supp. 377 (Sup. Ct. 1921). But cf. Davis \& Banker v. Metcalf, 131 Wash. 141, 229 Pac. 2 (1924); Public Service Ry. v. Barnett, 92 N. J. Eq. 372, 116 Atl. 793 (1921); Grand Rapid Ry. v. Stevens, 219 Mich. 332, 189 N. W. 2 (1922); Henly v. Sidone, 127 Atl. 520 (N. J. Eq. 1923); In re James, 98 Vt. 477, 129 Atl. 175 (1925); Kinder v. Looney, 283 S. W. 9 (Ark. 1926). 